\title{
Paradoxes of Signification
}

\author{
Stephen Read
}

University of St Andrews

slr@st-andrews.ac.uk

\begin{abstract}
Ian Rumfitt has recently drawn our attention to a couple of paradoxes of signification, claiming that although Thomas Bradwardine's "multiple-meanings" account of truth and signification can solve the first of them, it cannot solve the second. The paradoxes of signification were in fact much discussed by Bradwardine's successors in the fourteenth century. Bradwardine's solution appears to turn on a distinction between the principal and the consequential signification of an utterance. However, although such a distinction played an important role in his successors' theories, it is shown that Bradwardine's account of signification does not admit any such distinction, no part being prior to the others. Accordingly his solution, unlike those of his successors, does not fall prey to Rumfitt's paradoxes.
\end{abstract}

\section{Keywords}

truth - signification - liar paradox - Bradwardine - Swyneshed - Heytesbury - Eland - Fland Strode - Rumfitt

\section{A Paradox of Signification}

There is a natural relation between an utterance of a sentence in a context and what it signifies, or expresses. For example, the sentence 'I am a logician', uttered by me, signifies that I am a logician; an utterance of 'It was raining yesterday' signifies that it was raining at the place of utterance (or some other place determined by the context of utterance) on the previous day; an utterance of 'London is pretty', uttered in Europe at any time, signifies that London, England is pretty (uttered in North America, it might signify that London, Ontario is pretty). In each case, the context of utterance plays a greater or lesser role in 
determining what was signified or expressed. Signification is context-relative, where context includes speaker, place, time and perhaps other matters too.

Another feature of signification is intentional inexistence. For example, 'Unicorns live on Mars' signifies that unicorns live on Mars, even though there are no unicorns, and does not signify that hobbits live on Mars, even though the class of unicorns is co-extensive with that of hobbits. Moreover, utterances can be self-referential, e.g., the sign on the back of a car that reads 'If you can read this, you're too close'.

Consider an utterance of 'Things are not as this utterance signifies', uttered in a context where it is clear that self-reference is intended, and suppose things are as that utterance signifies - call the utterance $C$. On that assumption, it seems that things are indeed not as $C$ signifies. The general principle is that if $s$ signifies that $p$, and things are as $s$ signifies (in that context), then $p$, for any $s$ and $p$. So by reductio ad absurdum, discharging the assumption that things are as $C$ signifies, we can conclude that things certainly are not as $C$ signifies - they cannot be, on pain of contradiction. But then it seems to follow ineluctably that things are as $C$ signifies, for it signifies that things are not as it signifies. The seemingly compelling principle is that if $s$ signifies that $p$ (in some context), and $p$, then things are as $s$ signifies. Yet that really is a contradiction: we appear to have shown that things are both as $C$ signifies and not as $C$ signifies. How is that possible? We have a contradiction, and a paradox.

The reasoning in the previous paragraph is very similar to that in the more familiar Liar paradox, concerning an utterance of the sentence 'This utterance is false', taken as signifying of itself that it is false-call it $F$. Truth of an utterance $s$ (in a context) requires that things be as $s$ signifies (in that context), so if we suppose that $F$ is true, it follows that $F$ is false, and so not true (it cannot be both), so by reductio ad absurdum, $F$ is not true, discharging the assumption. So $F$ must be false, assuming that every declarative sentence is either true or false. But then things are as $F$ signifies (in that context), and again if $s$ signifies that $p$, and $p$, then surely $s$ is true. So $F$ is true, for things are as it signifies. That is, $F$ is both true and false, so both true and not true. We have contradiction and paradox once again. 


\section{Bradwardine}

Thomas Bradwardine's solution to the Liar paradox diagnosed a fallacy in this reasoning. ${ }^{1}$ He agreed that if $s$ signifies that $p$, then if $s$ is true, so is $p$; but he denied the converse, that if $p$ then $s$ is true. For $s$ may signify more than just that $p$. Signification is not only contextrelative and intensional, it is also multiple. It follows that the truth of $s$ requires that things be wholly as $s$ signifies. For example, an utterance of 'I am a logician' signifies not only that I am a logician, but also that someone is a logician, that I exist, and that logic exists and can be studied, and all of these must hold for it to be true; 'Unicorns live on Mars' signifies that unicorns are alive, something lives on Mars and Mars is somewhere to live; or to take Bradwardine's own example (Insolubilia, ad A.4.3), 'The heavens are everything' signifies that the heavens are not everything (for everything includes its proper parts, none of which is everything), in particular, that the heavens are not the heavens. Bradwardine (Insolubilia, 6.3) went so far as to claim that signification is closed under consequence, that an utterance signifies everything which follows from what it signifies.

Take the Liar sentence, $F$, once again. It signifies that $F$ is false. What else does it signify? Collect it all up as $\phi$, say, so $F$ signifies wholly that $F$ is false and $\phi$. Then if $F$ is false, things are not wholly as $F$ signifies, that is, not both $F$ is false and $\phi$. In other words, if $F$ is false, either not- $\phi$ or $F$ is not false but true (assuming again, as Bradwardine did, that every significant declarative utterance is either true or false), whence by Importation, if $F$ is false and $\phi, F$ is true. But we assumed that $F$ signifies that $F$ is false and $\phi$, so by the closure principle, $F$ also signifies that $F$ is true. Whatever $\phi$ covers, it must cover $F$ 's being true, so $F$ signifies both that $F$ is false and that $F$ is true. Hence, $F$ is implicitly contradictory, and things cannot be wholly as $F$ signifies. So $F$ is false and not true.

But given that $F$ is false, can we not infer contradiction again, that $F$ is true, since that is what $F$ signifies? No, says Bradwardine: he denies the seemingly compelling principle, that

\footnotetext{
${ }^{1}$ Bradwardine was archbishop of Canterbury when he died in 1349. His treatise on Insolubles-logical paradoxes like the Liar-was written more than 25 years earlier, when he was a teaching master at Oxford. See Thomas Bradwardine, Insolubilia, ed. and trans. S. Read (Leuven, 2010), Introduction $§ 1$.
} 
if $s$ signifies that $p$, and $p$, then $s$ is true. The truth of $F$ requires that things be wholly as $F$ signifies, not just that $F$ be false but that $F$ be true too. But it cannot be both, so it is simply false. This is the "multiple-meanings" solution to the semantic paradoxes.

The same diagnosis and solution can be applied to the paradox of signification, C. C cannot signify only that things are not as it signifies. For if it did, and things were not as it signified, things would be as it signified. Since it signifies that things are not as it signifies, it would follow by Bradwardine's closure principle that things would be as it signified. So it cannot signify only that things are not as it signifies - it must signify more than just that. So suppose $C$ signifies wholly that things are not as $C$ signifies and $\phi$, and again suppose things are not wholly as $C$ signifies. Then either not- $\phi$ or things are as $C$ signifies, so if things are not as $C$ signifies and $\phi$, things are as $C$ signifies. But we assumed that $C$ signifies that things are not as $C$ signifies and $\phi$, so by the closure principle, $C$ signifies that things are as $C$ signifies. So $C$ signifies both that things are not as it signifies and that they are. Hence, $C$ is implicitly contradictory, and things cannot be wholly as $C$ signifies. But we cannot infer its contradictory opposite, that things are as $C$ signifies, for they are not wholly as $C$ signifies. They are partly as $C$ signifies, for they are not as $C$ signifies, and $C$ signifies that. But $C$ also signifies that things are as it signifies, and they are not. So contradiction and paradox are avoided, and things are simply not as $C$ signifies. $^{2}$

Bradwardine imagines an opponent making a distinction (which, we will see, he does not himself endorse). Suppose Socrates says 'Socrates says something false' (Sortes dicit falsum) — call it $A$ - and nothing else:

But if $A$ signifies itself to be true, this is not principally, but consequentially. ${ }^{3}$

\footnotetext{
${ }^{2}$ Paradox $C$ and this response on Bradwardine's behalf were given in S. Read, "The Truth Schema and the Liar," Unity, Truth and the Liar: the Modern Relevance of Medieval Solutions to the Liar Paradox, ed. S. Rahman, T. Tulenheimo, and E. Genot (Berlin, 2008), 3-17, at 13-14.

${ }^{3}$ Thomas Bradwardine, Insolubilia, \$7.2.5 (ed. and trans. Read, 106-07): "Contra: si a significaret a esse verum, hoc non est principaliter, sed ex consequenti."
} 
The idea is that what $A$ principally signifies is that Socrates says something false; among what it signifies consequentially is that it itself is false, since the context is that it alone was what Socrates said, and further, that it itself is true, by an argument similar to that for $F$ above. Similarly, what $C$ principally signifies is that things are not as $C$ signifies; it signifies that things are as $C$ signifies only consequentially, as a consequence of its principal signification by the argument given above. The distinction became widespread among English logicians following Bradwardine, notably William Heytesbury, but also John Hunter, Robert Eland (on whom, see below), John of Holland, and a number of anonymous authors. ${ }^{4}$ Primary or principal signification was also described as signification sicut verba communiter praetendunt, that is, as the words commonly or usually signify or indicate.

However described, the distinction is dynamite, as Ian Rumfitt has recently observed. ${ }^{5}$ Let $D$ signify principally that things are not as $D$ principally signifies. Supposing that things are as $D$ principally signifies, it follows that things are not as $D$ principally signifies (for that is what $D$ principally signifies). So by reductio ad absurdum, things are not as $D$ principally signifies. Hence things are as $D$ principally signifies (for, to repeat, that is what $D$ principally signifies). Contradiction-and no mention has been made of $D$ 's consequential or secondary signification, so whatever it is, it can be of no avail in avoiding contradiction. Hence, if Rumfitt were correct in saying that Bradwardine's "theory presupposes a sharp distinction between the thought that a declarative utterance explicitly expresses au pied de la lettre (its primary signification...) and those thoughts that it signifies in other ways" (its secondary or consequential signification), the theory would be helpless in the face of the paradox of signification, at least in form $D$.

\section{Swyneshed}

\footnotetext{
${ }^{4}$ See, e.g., F. Pironet, "William Heytesbury and the Treatment of Insolubilia in Fourteenth-Century England Followed by a Critical Edition of Three Anonymous Treatises De Insolubilibus Inspired by Heytesbury," in Unity, Truth and the Liar, ed. Rahman, Tulenheimo, and Genot, 255-333.

${ }^{5}$ I. Rumfitt, "Truth and Meaning," Aristotelian Society Supplementary Volume 88 (2014), 21-55, at 45.

${ }^{6}$ Rumfitt, "Truth and Meaning," 45.
} 
Paradox $D$ is in fact found in Roger Swyneshed's Insolubilia, composed around ten years after Bradwardine's, in the early 1330s. ${ }^{7}$ It is preceded in the text by paradox $C$. Swyneshed's response to the two sophisms (as he calls them) is given in a final section of the treatise which is advertised as dealing with "some sophisms which appear to be insolubles but are not." The whole discussion is framed in the language of obligations, of positing, granting, denying and doubting utterances, rather than directly discussing whether they are true or false. ${ }^{8}$ He dismisses $C$ and $D$ as neither true nor false (in contrast to insolubles, which he claims "falsify themselves"). He writes briefly of $D$ near the end of the treatise:

Similarly, if 'Things are not as this utterance principally signifies' is posited, and supposing that it principally signifies in that way, namely, that things are not as it principally signifies, where 'this' points to that same [utterance], then 'Things are not as it principally signifies' should be granted, and it should be said that it does not signify as things are nor other than they are, as in the earlier sophism. ${ }^{9}$

This is all he has to say about $D$; he deals with $C$ at much greater length.

The key to Swyneshed's solution to the insolubles is that they falsify themselves, which he builds into the definition of truth and falsehood:

\footnotetext{
${ }^{7}$ Roger Swyneshed (or Suisset) is not to be confused with the better-known Merton Calculator, Richard Swyneshed (or Swineshead). He wrote treatises on Insolubles and Obligations between 1330 and 1335. Subsequently, he became master of theology (though his Sentences lectures seem not to have survived) and a Benedictine monk of Glastonbury. He died about 1365. See J. Weisheipl, "Roger Swyneshed OSB, Logician, Natural Philosopher, and Theologian," in Studies Presented to Daniel Callus (Oxford, 1964), 231-252.

${ }^{8}$ On the theory of obligations, see, e.g., P.V. Spade and M. Yrjönsuuri, "Medieval Theories of Obligationes," in The Stanford Encyclopedia of Philosophy, ed. E.N. Zalta (Winter 2014 edition), online.

${ }^{9}$ Rogerus de Swyneshed, Insolubilia, §109, ed. P.V. Spade, "Roger Swyneshed's 'Insolubilia': Edition and Comments," Archives d'histoire doctrinale et littéraire du moyen âge 46 [1979], 177-220, at 219; reprinted in P.V. Spade, Lies, Language and Logic in the Late Middle Ages [London, 1988], study VII): "Simile est si ponatur illa 'Non est ita sicut illa propositio principaliter significat' et quod illa principaliter sic significet, scilicet, quod non est ita sicut illa principaliter significat, et quod per ly 'ista' demonstretur illa eadem. Hoc posito, concedenda est illa 'Non est ita sicut illa principaliter significat'. Et dicendum quod illa non significat sicut est nec aliter quam est, ut in priori sophismate." Except where stated, translations from the Latin are my own.
} 
A true utterance is one not falsifying itself that principally signifies as things are naturally or by a convention by which it was last imposed to signify... A false utterance is one falsifying itself or one not falsifying itself that principally signifies other than things are naturally or by a convention by which it was last imposed to signify. ${ }^{10}$

Thus, in determining the truth of an utterance, falsifying itself trumps things being as it signifies. If an utterance falsifies itself it is, as one would expect from the term, false, regardless of how it signifies in other respects and regardless of how things are. So what is it for an utterance to falsify itself? Such an utterance is, Swyneshed writes, one that is "relevant to inferring that it itself is false." 11 Take $F$, for example, which signifies that it is false. Then we can immediately infer from $F$ that $F$ is false, so $F$ falsifies itself, and Swyneshed's account of truth and falsehood decrees that $F$ is false and not true despite the fact that things are as $F$ signifies (namely, that $F$ is false). As Spade puts it, ${ }^{12}$ Swyneshed rejects semantic ascent, otherwise known as, e.g., Upward T-Inference, ${ }^{13}$ just as we noted earlier that Bradwardine does: we cannot infer the truth of $s$ from the fact that $s$ signifies that $p$, and $p$. For Bradwardine, we need to know that things are wholly as $s$ signifies; for Swyneshed, we need to know not only that things are as $s$ principally signifies, but also that $s$ does not falsify itself.

\footnotetext{
${ }^{10}$ Swyneshed, Insolubilia, $§ \S 14-15$ (ed. Spade, 185-186): "Propositio vera est propositio non falsificans se principaliter sicut est significans naturaliter aut ex impositione vel impositionibus qua vel quibus ultimo fuit imposita ad significandum... Propositio falsa est oratio falsificans se vel oratio non falsificans se principaliter aliter quam est significans naturaliter, ex impositione, vel impositionibus qua vel quibus ultimo fuit imposita ad significandum." An alternative translation is given by Spade in William Heytesbury, On "Insoluble" Sentences: Chapter One of His Rules for Solving Sophisms, trans. P.V. Spade (Toronto, 1979), 72. Utterances that signify naturally are mental propositions; utterances that signify by convention are spoken and written sentences whose signification can be changed by special convention (impositio) in the course of an obligational disputation (or in other ways): see, e.g., Spade and Yrjönsuuri, "Medieval Theories of Obligationes," §5.

${ }^{11}$ Swyneshed, Insolubilia, §5 (ed. Spade, 182): "pertinens ad inferendum se ipsam fore falsam."

12 P.V. Spade, "Roger Swyneshed's Theory of 'Insolubilia': A Study of Some of His Preliminary Semantic Notions," History of Semiotics, ed. A. Eschbach and J. Trabant ( Amsterdam/Philadelphia, 1983), 105-113, at 106; reprinted in Spade, Lies, Language and Logic in the Late Middle Ages, study VIII.

${ }^{13}$ See T. Maudlin, Truth and Paradox (Oxford, 2004), 8.
} 
Aristotle had famously said in his Sophistical Refutations (ch. 25) that the paradox of the one who swears that he swears falsely commits the fallacy of relative and absolute (secundum quid et simpliciter). Both Bradwardine and Swyneshed feel that they must show that their solutions to the insolubles accord with Aristotle's authority. Bradwardine explains that, e.g., $A$ above ('Socrates says something false') is true secundum quid, that is, relative to part of what it signifies, namely, that $A$ is false, but false absolutely, that is, taking into account its total signification, whereby it also signifies that it is true. ${ }^{14}$ Swyneshed's account is a little different in this regard, but he also attributes the paradox to a fallacy of relative and absolute. He writes:

It must be recognised that the consequence 'This utterance [viz 'There is a falsehood' (falsum est) in a context where this is the only utterance] signifies principally as things are, so this utterance is true' is a fallacy of relative and absolute in that the premise falsifies itself formally. For an utterance to be true it is necessary that it signifies as things are and does not falsify itself in that context. But the premise only supports the conclusion relative to one part of its signification and not according to the other. So to argue from the premises to the conclusion is a fallacy of relative and absolute, just as when it is argued 'He is white as regards his teeth, so he is white'. ${ }^{15}$

Implicit in this diagnosis is that 'There is a falsehood' also signifies that it itself is false (when it is the only thing said) in addition to its principal signification. The implication is borne out by Swyneshed's subsequent remark that 'Every universal utterance differs from these [in truth-value]' (in a context in which the only other utterances are two true

\footnotetext{
${ }^{14}$ See, e.g., C. Dutilh Novaes and S. Read, "Insolubilia and the Fallacy secundum quid et simpliciter," Vivarium 46 (2008), 175-191.

${ }^{15}$ Swyneshed, Insolubilia, $§ 52$ (ed. Spade, 198): "Pro illo est admittendum quod talis consequentia 'Haec propositio significat principaliter sicut est; igitur, haec propositio est vera' est fallacia secundum quid et simpliciter eo quod antecedens formaliter falsificat se. Nam ad hoc quod aliqua propositio sit vera requiritur quod significet sicut est et non falsificat se cum hoc; sed antecedens solum ponit consequens secundum unam partem sui significati et secundum aliam non; ideo arguere a tali antecedente ad tale consequens est fallacia secundum quid et simpliciter, ut si arguitur sic 'Ille est albus secundum dentes; igitur, ille est albus'." The familiar example of the Ethiopean, who is black although his teeth are white, is found in Aristotle's Sophistical Refutations, ch. 5: 167a11.
} 
particulars) also signifies itself to be false, in addition to its principal signification, and so falsifies itself. ${ }^{16}$

However, Swyneshed does not claim that paradoxes $C$ and $D$ falsify themselves, and denies that they are false. That is why he dismisses them as not really insolubles. Rather than implying their own falsity, he says, they imply that they do not signify as things are, and so are neither true nor false since they neither signify as things are, nor otherwise. We have seen why $C$ and $D$ do not signify wholly as things are: for if they did, they would not signify as things are, so leading to contradiction, and hence they do not signify wholly, or even principally, as things are, and so not as things are. But why do they not signify other than things are, and how does the implication that they do not signify as things are ensure this? We need a further definition, parallel to the definition of falsehood, to the effect that an utterance does not signify that things are other than they are if it implies that it does not signify as things are. This lacks the plausibility, perhaps only verbal, that Swyneshed's disjunctive definition of falsehood has, namely, that an utterance is false either if it falsifies itself, or if things are other than it signifies. Nonetheless, we find it stated right at the beginning of Swyneshed's treatise:

An utterance signifying principally neither as things are nor other than they are, that is, which is neither true nor false, is an utterance signifying things to be in some way and which so signifying is relevant to inferring itself not to signify principally as things are, e.g., the utterance 'This utterance does not signify [principally] as things are. $^{17}$

Swyneshed is notorious for his iconoclastic proposals, the most famous being his responsio nova for obligations, which claims, inter alia, that a conjunction can be denied even when its conjuncts have been granted, and a disjunction can be granted even when its

\footnotetext{
${ }^{16}$ Swyneshed, Insolubilia, §59 (ed. Spade, 201).

17 Swyneshed, Insolubilia, §2 (ed. Spade, 180-181): "Propositio nec principaliter significans sicut est nec aliter quam est, id est, quae nec est vera nec falsa, est propositio significans aliqualiter esse et illa sic significando est pertinens ad inferendum se ipsam non significare principaliter sicut est, sicut haec propositio 'Haec propositio non significat [principaliter-add. ms C] sicut est', demonstrata illa eadem."
} 
disjuncts have been denied. ${ }^{18}$ Other radical claims of his are given in $\S 4$ below. But to claim that an utterance might signify neither as things are nor other than they are was a step too far for Paul of Venice, whose own solution to the insolubles in his Logica Magna otherwise follows Swyneshed's closely. Discussing paradox $C$, Paul wrote:

Let $A$ be 'This utterance signifies other than things are' referring to itself, explicitly signifying in this way... [and] let $B$ be an utterance signifying explicitly that it signifies other than things are, referring to $A$... I say, accepting the scenario, that things are not wholly as $A$ signifies, and so consequently, I concede that $A$ signifies other than things are. And then to the argument, " $A$ signifies other than things are, and $B$ signifies only that $A$ signifies other than things are, so things are wholly as $B$ signifies": I grant the inference and the conclusion; and then to the argument, "things are wholly as $B$ signifies and utterance $A$ wholly signifies like $B$ and vice versa, therefore things are wholly as $A$ signifies": I deny the inference, but it should be added in the premise that it is not inconsistent that $A$ is true, and this I deny. For $A$ falsifies itself, in that it asserts itself to signify other than things are, and this is why it is inconsistent for $A$ to be true. ${ }^{19}$

Thus Paul, unlike Swyneshed, accepts paradox $C$ as an insoluble, and says that it is false because it falsifies itself, since it signifies that it signifies that things are other than they are.

\footnotetext{
${ }^{18}$ Rogerus de Swyneshed, Obligationes, $\$ 32$ (ed. P.V. Spade, "Roger Swyneshed's Obligationes: Edition and Comments," Archives d'histoire doctrinale et littéraire du moyen âge 44 (1977), 243-285, at 257; reprinted in Spade, Lies, Language and Logic in the Late Middle Ages, study XVI): "Propter concessionem partium copulativae non est copulativa concedenda nec propter concessionem disjunctivae est aliqua pars ejus concedenda."

${ }^{19}$ Paulus Venetus, Logica Magna, pars II, tract. 15: "Insolubilia" (ed. Venice, 1499, ff. 195vb-196ra; corrected against ms. Città del Vaticano, BAV, Vat. lat. 2132, f. 240va): "Pono quod a sit illa hec propositio significat aliter quam est, eadem demonstrata, que precise sic significet... [et] ponatur quod b sit una propositio precise significans quod hec significat aliter quam est, demonstrata a... Dico admisso casu quod non est ita totaliter sicut a significat, et ita consequenter concedo quod a significat aliter quam est. Et tunc ad argumentum: a propositio significat aliter quam est et $b$ significat solummodo quod a significat aliter quam est, igitur ita est totaliter sicut b significat: concedo consequentiam et consequens: et tunc ad argumentum: ita est totaliter sicut $b$ significat et a propositio totaliter significat sicut b et econtra, igitur ita est totaliter sicut a propositio significat: nego consequentiam, sed deberet addi in antecedente quod non repugnat a esse verum et hoc negatur. Unde a falsificat se ex quo asserit se significare aliter quam est, quare repugnat a esse verum." Unfortunately, Paul does not discuss paradox $D$.
} 


\section{Heytesbury, Strode and Eland}

Arguments specifically against Swyneshed's position are found in treatises on insolubles by Robert Eland ${ }^{20}$ and a little later by Ralph Strode, writing in $1359 .^{21}$ Spade appends to his edition of Fland's Insolubles a transcription of part of Strode's treatise:

Concerning the second theory, namely, that of master Roger Swyneshed, it should be realised that the second member of the first division, sc. 'Some utterance neither signifies principally as things are nor other than they are', seems to be quite expressly contrary to age-old principles passed down by the most highly regarded philosophers... Then briefly against this theory, [Eland] ${ }^{22}$ adduces in his Insolubles some conclusions that follow from this theory but seem impossible. ${ }^{23}$

Strode and Eland each set out nine conclusions, as in Figures 1-2, against a briefer set of objections given by Heytesbury.

\footnotetext{
${ }^{20}$ I have argued in "Robert Fland-or Elandus Dialecticus?" (to appear) that Spade has misidentified the author of this treatise, and others on consequences and on obligations, which he attributes to an otherwise unknown author, Robert Fland. It should rather be attributed to Robert Eland, recorded by J. Bale, Scriptorum illustrium Maioris Britanniae Catalogus, Centuria xii, no. 38 (Basel, 1559) vol. 2, 86, as Eland the Dialectician (Elandus Dialecticus).

${ }^{21}$ See A. Maierù, "Le ms. Oxford canonici misc. 219 et la "Logica" de Strode'," in Engish Logic in Italy in the 14th and 15th Centuries, ed. idem (Naples, 1982), 87-110, at 89. Strode was a fellow of Merton College in the 1350s and 1360s, where he composed a Logica containing treatises on insolubles, suppositions, consequences and obligations. In the 1380s he was living next door to the poet Geoffrey Chaucer in Cheapside in London. Chaucer dedicated his poem Troilus and Criseyde to the poet John Gower and to Strode.

${ }^{22}$ Strode's treatise survives in three manuscripts, but two are seriously incomplete, containing only about a third of the work. The passage P.V. Spade cites occurs in just one manuscript, and the expression given here as 'Eland' is transcribed by Spade as 'Heytesbury'. Consequently, Spade, in "Robert Fland's Insolubilia: An Edition, with Comments on the Dating of Fland's Works," Mediaeval Studies 40 (1978), 56-80, at 61, claims that Strode attributes these arguments to William Heytesbury. In his unpublished edition of Strode's treatise, Alfonso Maierù renders the expression 'Elan〈d $\rangle$ '.

${ }^{23}$ Radulphus Strode, Insolubilia, §§1-2 (ed. Spade, "Robert Fland's Insolubilia," 76, but amended here): "Circa secundam opinionem, videlicet, magistri Rogeri Swinised, est sciendum quod secundum membrum primae divisionis, ista, scilicet, 'Aliqua propositio nec principaliter significat sicut est nec aliter quam est', videtur satis expresse esse contra antiqua principia a philosophis maxime approbatis tradita... Unde breviter contra istam opinionem adducit $<$ Eland $>$ in suis insolubilibus quasdam conclusiones ut videtur impossibiles, quae ex ista opinione sequuntur."
} 
Figure 1: The Nine Impossible Conclusions of Swyneshed's Theory

Strode $\quad$ Eland $\quad$ Heytesbury $^{24}$

\begin{tabular}{|c|c|c|c|}
\hline 1 & $\begin{array}{l}\text { Aliqua propositio est falsa } \\
\text { que precise significat sicud } \\
\text { est }\end{array}$ & $\begin{array}{l}\text { Propositio falsa significat } \\
\text { praecise sicut est }\end{array}$ & $\begin{array}{l}\text { Ex casu patet duo } \\
\text { contradictoria sequi }\end{array}$ \\
\hline 2 & $\begin{array}{l}\text { Duo contradictoria sibi } \\
\text { invicem contradicentia sunt } \\
\text { simul falsa }\end{array}$ & $\begin{array}{l}\text { Duo contradictoria } \\
\text { simul falsa }\end{array}$ & $\begin{array}{l}\text { Qui ponit duo } \\
\text { contradictoria esse simul } \\
\text { falsa }\end{array}$ \\
\hline
\end{tabular}

3 In consequentia bona et Ex vero sequitur falsum Ex vero sequitur falsum formali ex vero sequitur formaliter in consequentia bona et falsum formali

4 Aliqua est consequentia Aliqua consequentia est Verum convertitur cum bona, cuius consequens est bona cujus consequens est falso et ... eadem verum et antecedens nec verum et antecedens nec propositio simplex verum nec falsum significat sicut est nec aliter quam est contradicit uni false et uni vere

5 Aliqua est consequentia bona Aliqua consequentia est Aliud quam necessarium et formalis, cuius antecedens est verum et consequens nec antecedens est falsum et verum nec falsum consequens neque significat sicut est nec aliter quam est

6 Aliqua sunt duo Sunt duo contradictoria

Due sunt propositiones contradictoria, quorum unum quorum unum est verum et est verum et reliquum nec reliquum neque verum significans sicud est nec neque falsum impossibili ... et tamen aliter quam est et per ... quarum quelibet contradicit eidem una illarum est

\footnotetext{
${ }^{24}$ Guillelmus Heytesbury, Regulae solvendi sophismata, "De insolubilibus" (ed. Venice, 1494, f. 5ra-b)
} discussed by Spade in Heytesbury, On "Insoluble" Sentences, 77-78. 
consequens secundum istam

opinionem nec verum nec

falsum

7 Alique due propositiones Qualitercumque significat a convertuntur simpliciter, significat $b$ et $b$ non quarum una est falsa et convertitur cum a, vel reliqua nec vera nec falsa, et propositio nec significans quarum una significat aliter sicut est nec aliter quam est quam est et reliqua nec convertitur cum significat aliter quam est nec propositionefalsa sicud est

8 Aliqua propositio est falsa Propositio falsa nec que aliqualiter significat, que significat sicut est nec aliter tamen nec significat sicud est quam est nec aliter quam est

9 Iste due propositones stant Ita est totaliter sicut Sortes simul: 'ita est totaliter sicud dicit et non est ita totaliter Sortes dicit' et 'non est ita sicut Sortes dicit totaliter sicud Sortes dicit' necessaria ... et alia contingens non necessaria

Aliqua sit propositio vera que nec scit [sic!] necessaria nec contingens

Figure 2: The Nine Impossible Conclusions of Swyneshed's Theory Strode Eland Heytesbury

\footnotetext{
1 Some utterance is false which A false utterance signifies Two contradictories precisely signifies as things are precisely as things are follow from the same casus

2 Two contradictories mutually Two contradictories are at Two contradictories contradicting each other are at the same time false are at the same time the same time false false
} 
3 In a good and formal The false follows formally A falsehood follows consequence the false follows from the true from a truth in a valid from the true formal consequence

4 Some consequence is good Some consequence is good A truth is convertible whose consequent is true and whose consequent is true with a falsehood and antecedent neither true nor false and antecedent neither the same simple signifies as things are nor utterance contradicts a other than they are false one and a true one

5 Some consequence is good and formal, whose antecedent is true and consequent neither true nor false

antecedent is false and the consequent neither signifies as things are nor other than they are

6 There are two contradictories of which one is true and the other neither signifying as things are nor other than they are and consequently according to this opinion neither true nor false

There are two Two utterances may contradictories of which contradict the same one is true and the other impossible utterance, neither true nor false yet the first is necessary and the second contingent

7 There are two utterances which In whatever way $A$ signifies convert simply of which one is $B$ signifies and $B$ does not false and the other neither true nor false, and of which one signifies other than things are and the other neither signifies things are converts with a

\footnotetext{
${ }^{25}$ Here, $A$ is 'This signifies other than things are', referring to itself, and $B$ is 'This signifies other than things are', referring to $A$.
} 
other than things are nor as false utterance

things are

8 Some utterance is false which A false utterance neither signifies in some way, but signifies as things are nor which neither signifies as things other than they are are nor other than they are

9 These two utterances stand Things are wholly as together: 'Things are wholly as Socrates says and things are Socrates says' and 'Things are not wholly as Socrates says not wholly as Socrates says' 
The close similarities between Strode's and Eland's objections, and their differences from those in Heytesbury, strongly suggest that Strode drew his objections directly from Eland. Three of the nine "impossible conclusions" are in fact presented by Swyneshed himself, together with objections to which he replies. They are that some false utterance (e.g., $F$ ) signifies as things are; that some formally valid consequence (viz 'The conclusion of this consequence is false, so this conclusion is false') has true premise and false conclusion; and that a pair of mutual contradictories ( $v i z$ ' $F$ is false' and ' $F$ is not false') are both false. While Swyneshed presents them as exciting discoveries, Strode and Eland see them as unacceptable and contrary to both ancient and modern wisdom. ${ }^{26}$

But what seems to exercise Strode and Eland most concerns the further conclusions that they draw, which they see as flatly contradicting central Aristotelian doctrines as expressed in the Organon (referring explicitly to the Categories, De interpretatione, Prior and Posterior Analytics and Topics) and in the Metaphysics, arising from Swyneshed's claim that a significant utterance might signify principally neither as things are nor other than they are, and so might be neither true nor false. How can the conclusion of a valid consequence lack truth-value if the premise is true? How can one of a pair of contradictories or of equivalents lack truth-value if the other is true? How can a false utterance signify in some way but neither signify as things are nor other than they are? Finally, Swyneshed's theory seems to entail that if Socrates utters 'Things are not as Socrates says' then things both are and are not wholly as Socrates says: "But it is clear that this conclusion is impossible, because it implies that mutual contradictories are at the same time true., 27

Bradwardine's theory has consequences similar to the first three of these conclusions, but he sticks firmly to bivalence (that every utterance is either true or false). Moreover, Bradwardine can explain them with less violence to logic than Swyneshed, who claims in his third conclusion, as noted above, that two contradictories are both false. For example, a self-referential utterance of ' $F$ is false' is false, and so ' $F$ is not false' is also false. But the

\footnotetext{
${ }^{26}$ Strode, Insolubilia, §1; Eland, Insolubilia, $\$ 35$ (ed. Spade, "Robert Fland's Insolubilia," 76 and 68).

27 Strode, Insolubilia, $\S \S 1-2$ (ed. Spade, 80): "Sed clarum est quod ista conclusio est impossibilis, quia implicat contradictoria sibi invicem contradicentia esse simul vera."
} 
explanation, as Bradwardine says, $^{28}$ is that these two utterances are not really contradictories, any more than are, e.g., 'Some men are running' and 'Some men are not running' or 'The king of France is bald' and 'The king of France is not bald'. The contradictory of the self-contradictory $F$ is, unsurprisingly, a tautology, viz 'Either $F$ is not false or $F$ is not true', that is, 'Not: $F$ is false and $F$ is true', spelling out its signification (by Bradwardine's lights) in full.

Eland, in fact, offers his readers a choice between two solutions to these paradoxes, Bradwardine's or Heytesbury's. ${ }^{29}$ Heytesbury's response became more popular than Bradwardine's, and does not depend on Bradwardine's strong closure postulate to determine the multiple meanings of an utterance. Indeed, Heytesbury's theory abnegates all responsibility for specifying what the secondary or consequential meaning of an insoluble is. Cast thoroughly in the language of obligations theory, Heytesbury agrees that insolubles must mean more than their principal or usual signification, but denies that he needs to specify what that further signification is. Suppose we have an obligational casus in which Socrates utters 'What Socrates says is false' and nothing else:

But if someone asks under this casus what the sentence uttered in this way by Socrates signified other than that Socrates is saying what is false, I say to him that the respondent does not have to solve or to give his determination for that question. For from the casus it follows that the sentence signifies otherwise than that Socrates is saying what is false, but the casus does not specify what that is; hence, the respondent does not have to give any further determination for that question. ${ }^{30}$

\footnotetext{
${ }^{28}$ Bradwardine, Insolubilia, §ad 7.3 (ed. and trans. Read, 108-09).

${ }^{29}$ Heytesbury was another of the Oxford Calculators. Fellow of Merton College by 1330, he composed his Rules for Solving Sophisms (Regulae) in 1335. During the 1330s he also wrote a treatise on On Compounded and Divided Senses, a collection of Sophismata, another called Sophismata Asinina (see Guillaume Heytesbury, Sophismata Asinina, ed. F. Pironet [Paris, 1994]) where each sophism is tailored to establish the paradoxical conclusion 'You are an ass', and a pedagogical treatise on consequences, Iuxta Hunc Textum. He was doctor of theology by 1348 and chancellor of the University of Oxford from 1352 till perhaps 1354 and again from 1370 to 1372 . He died in 1372/73. See, e.g., Spade's 'Introduction' to Heytesbury, On "Insoluble" Sentences.

${ }^{30}$ Heytesbury, On "Insoluble" Sentences, §51 (trans. Spade, 49-50). See Heytesbury, Regulae solvendi sophismata, "De Insolubilibus" (ed. Venice, f. 6va): "Si autem queratur in isto casu quid significavit ista propositio sic dicta a sorte aliter quam quod sortes dicit falsum: huic dicitur quod respondens non habet istam
} 
All Heytesbury will admit is that 'What Socrates says is false' is implicitly contradictory and so its truth must be denied, even though it follows that what Socrates says is false.

Where Eland offers a choice between Bradwardine's and Heytesbury's theories, Strode offers a combination of the two. ${ }^{31}$ He rejects Bradwardine's closure postulate, but is also unhappy with Heytesbury's agnosticism about what the secondary signification of insolubles is. Insolubles like $F$, he says, signify their own truth secondarily.

But what of $C$ and $D$ ? As we have seen in $\S 3$, these are solved by Swyneshed by declaring them truth-valueless, but at the cost of imposing an apparently ad hoc requirement that an utterance only signifies principally as things are if it is not relevant to inferring itself not to signify principally other than things are, and of denying not just bivalence for some significant utterances but even denying that they either signify as things are or other than they are. Bradwardine and Heytesbury can solve paradox $C$ by claiming that it signifies more than just what it principally signifies, viz that things are not as it signifies, in Bradwardine's case that it also signifies that things are that way, so that although things are not as it signifies, and it signifies just that, things are not wholly as it signifies; similarly for Heytesbury, though he refuses to divulge, or even enquire what else it signifies.

But that still leaves paradox $D$ : 'Things are not as $D$ principally signifies'. It appears both that things are as it principally signifies and that they are not as it principally signifies. Is there anything that Bradwardine or Heytesbury, or Eland or Strode, or we, can do to retrieve the situation?

\section{Principal and Consequential Signification}

questionem solvere seu determinare: quia ex casu sequitur quod illa propositio aliter significat quam quod sortes dicit falsum: sed casus non certificat quid illud sit ideo non habet respondens quesitum illud ulterius determinare." Cf. Pironet, "William Heytesbury and the Treatment of Insolubilia," 286.

${ }^{31}$ See, e.g., P.V. Spade, The Mediaeval Liar: A Catalogue of the Insolubilia-Literature (Toronto, 1975), 8990. 
As remarked earlier, Bradwardine speaks of the principal as opposed to the consequential signification of an utterance only in an objection. The objection, essentially a "revenge" paradox, focusses on Bradwardine's claim (call it $B$ ) that Socrates' utterance of $A$, 'Socrates utters something false', is false, since $A$ signifies itself to be both true and false. This is puzzling, for did not Socrates and Bradwardine say the same thing? Bradwardine denies this. $A$ signifies that $A$ is true (as well as false), but $B$ does not. For $A$ is selfreferential, and $B$ is not. The opponent tries to show that $A$ and $B$ are equivalent, and so that Bradwardine's assessment of $A$ as false contradicts itself:

But if $A$ signifies itself to be true, this is not principally, but consequentially, because $A$ 's being true follows from $A$ 's being false, as was proved above. Since, therefore, $B$ signifies $A$ 's being false, as can be proved in the way it was earlier proved that $A$ signifies $A$ 's being false, it follows that from $B$ it follows that $A$ is true, and so $B$ signifies consequentially that $A$ is true, and so $[B$ signifies the same as $A$, so $A$ and $B$ are equivalent]. ${ }^{32}$

In reply, Bradwardine makes a further distinction. Signifying something principally, Bradwardine says, can happen in two ways: either by first (primo) representing it to the mind, or by signifying it in itself (per se) and not because it only follows from its significate. Take 'Only $S$ is $P$ ', an example of what the medievals called an exclusive sentence. It is exponible, that is, analysable into a conjunction of sentences, its exponents, namely, ' $S$ is $P$ ' (its affirmative exponent) and 'Nothing other than $S$ is $P$ ' (its negative exponent). Bradwardine claims that in the first way 'Only $S$ is $P$ ' principally signifies its affirmative exponent but not its negative exponent; in the second way, it principally signifies both exponents - that is, both exponents are principal. They are both what it signifies:

\footnotetext{
${ }^{32}$ Bradwardine, Insolubilia, $\$ 7.2 .5$ (ed. and trans. S. Read, 106-07): "Contra: si a significaret a esse verum, hoc non est principaliter, sed ex consequenti; sed quia a esse verum sequitur ad a esse falsum, sicut prius fuit deductum, cum ergo b significet a esse falsum, ut potest probari sicut prius probabatur a significare a esse falsum, sequitur quod ex b sequitur a esse verum; ergo b ex consequenti significat a esse verum, ergo et cetera."
} 
Reply: Something's principally signifying something else is two-fold: either because it first represents that thing to the mind, or because it signifies it, not because it follows from its significate, but [because] in itself it is signified by it. For example: an affirmative exclusive, speaking in the first way, signifies its affirmative exponent principally, and not the negative one; speaking in the second way, it signifies its negative exponent principally, as well as the affirmative. ${ }^{33}$

Bradwardine goes on to say that consequential signification can be taken in the same two ways. Presumably, he means that in one sense, the consequential signification is not first represented to the mind; in the other, that it is not what the expression signifies in itself, but merely follows from what it so signifies. Consequently, he says, the objection fails, and he proceeds to spell out why it fails. The argument in his second conclusion did not show that $A$ 's being true follows from $A$ 's being false. Rather, he reminds us, "from $A$ 's signifying itself to be false it was earlier deduced with certain truths that $A$ signifies itself to be true." 34 It would clearly be disastrous for Bradwardine to concede that if $A$ is false then $A$ is true. For his solution to the paradox says that $A$ is false, so if $A$ 's truth really followed from its falsehood, it would follow that $A$ was also true and paradox would have returned with a vengeance. But $A$ 's truth does not simply follow from its falsehood, as Bradwardine says, and the argument that $A$ signifies its own truth does not depend on deriving $A$ 's truth from its falsehood. Recall the argument concerning $F$ from $\S 2$ above. Bradwardine generalizes the argument, ${ }^{35}$ giving it for any utterance $s$ which signifies of itself that it is not true, or that it is false: if $s$ signifies that $s$ is false, and nothing else, then if $s$ is false, things are not as it signifies, that is, $s$ is not false but true. But $s$ signifies that $s$

\footnotetext{
33 Bradwardine, Insolubilia, §ad 7.2.5 (ed. and trans. Read, 108-09): "Ad illud dicendum quod aliquid significare aliud principaliter dupliciter est: aut quia primo representat idem intellectui, aut quia significat idem, non quia sequitur ex suo significato, sed per se significatur per illud. Verbi gratia: exclusiva affirmativa, primo modo loquendo, significat suam affirmativam exponentem principaliter et non negativam; secundo modo loquendo, significat exponentem negativam principaliter et etiam affirmativam."

${ }^{34}$ Bradwardine, Insolubilia, §ad 7.2.5 (ed. and trans. Read, 108-09): "... ex a significare se esse falsum, cum quibusdam veris prius erat deductum a significare se esse verum."

${ }^{35}$ Bradwardine, Insolubilia, §6.6.1 (ed. and trans. Read, 102-03).
} 
is false, so by the closure postulate, $s$ signifies that $s$ is true. So $s$ does not signify only that $s$ is false, but also that $s$ is true. To be sure, in the course of this reasoning, we seem to have shown that if $s$ is false, then $s$ is true, that is, we have inferred $s$ 's being true from $s$ 's being false. But that was on the false hypothesis that $s$ signified only that $s$ is false, and we have reduced that hypothesis to absurdity.

So if $s$ signifies that $s$ is false, it also signifies more, call it $\varphi$, so $s$ signifies wholly that $s$ is false and $\varphi$. Then if $s$ is false, things are not wholly as it signifies, that is, either $s$ is true or not- $\varphi$, i.e., if $\varphi$ then $s$ is true. So by Importation, if $s$ is false and $\varphi$ then $s$ is true. But $s$ signifies that $s$ is false and $\varphi$, so by the closure postulate once more, $s$ signifies that $s$ is true. Hence any utterance, $F, A$ or whatever, that signifies that it itself is false, also signifies that it is true. But, even though it is Bradwardine's closure postulate that reveals that it signifies more than simply that it is false (as we noted in $\S 4$ ), that further signification is not consequential on what it principally signifies, or on what it immediately (primo) represents to the mind. It is just part of what it signifies.

As Bradwardine observes, we have not shown here that if $A$ is false then $A$ is true. Rather, we showed that if $A$ is false (and so not true) and $\varphi$ (for the relevant $\varphi$ ) then $A$ is true, and so that if $A$ signifies that $A$ is false and $\varphi$ then $A$ signifies that $A$ is true. That is, $A$ 's truth does not follow from its falsehood, but from its signifying its own falsehood together with its signifying that $\varphi$. Indeed, this is trivial, for $\varphi$ encapsulates everything else that $A$ signifies, in particular, that $A$ is true. ${ }^{36}$

\section{Concluding Remarks}

To return to the paradox of signification: the form of paradox $D$ depends, as Rumfitt observed, on there being a clear distinction between its principal signification and its consequential signification. But that distinction is not clear at all. $C$ 's signifying as things

\footnotetext{
${ }^{36}$ Nonetheless, Bradwardine has left us a puzzle here. For he writes, as we noted above, "it was earlier deduced with certain truths that $A$ signifies itself to be true." To be sure, that $A$ is true does not follow simply from the assumption that $A$ is false, but only from the assumption that $A$ is false and $\varphi$. But the members of $\varphi$ are not all true, in particular, it is not true that $\varphi$ is true.
} 
are is not a consequence of things not being as $C$ signifies. They are both just among the things it signifies, and neither is prior to the other. Nor is F's signifying its own truth consequential on its signifying its own falsehood. They are each among what $F$ signifies, but no sense has yet been given to the idea of one's being principal and the other secondary or consequential. If we try to stipulate that $D$ principally signifies that things are not as it signifies, we have not so far given it any signification different from that of $C$. $D$ signifies both that things are as it signifies, and that things are not as it signifies. Again, neither is prior to the other, nor is one principal and the other consequential. Spade suggests an analogy: 'John kicked the ball over the fence' "partially" signifies that John kicked the ball, and partially that the ball went over the fence. ${ }^{37}$ But neither of those is in any clear sense a consequence of what the other signifies. They are only consequences of what the sentence as a whole signifies. The same is true of $C$ and $F: C$ partially signifies that things are not as it signifies, and partially that they are; $F$ partially signifies that it itself is false, and partially that it is true. They are part of what it signifies, and consequential on its whole signification, but neither part is prior to the other, nor is either consequential on the other. Nor does any paradox follow from the utterance 'Things are not as this utterance partially signifies', or even 'Things are partially not as this utterance signifies'.

We search in vain in Bradwardine's successors for any better account of principal signification. As noted in $\S 2$ above, they often use the phrase 'as the words usually signify' (sicut verba communiter pretendunt). ${ }^{38}$ But there is no such thing. Signification is always relative to a context, and there is no plausible account of 'usually'. Suppose we take 'usually' to mean 'non-insoluble': $B$, for example, signifies that what Socrates utters is false. Suppose Socrates had actually said, 'I know nothing'. It would follow that $B$ signified that Socrates knows something. So Socrates' knowing something would be part of the principal signification of $B$ if we identify its principal signification with its signification in non-insoluble contexts. But of course, if Socrates had said something else, e.g., 'John

\footnotetext{
${ }^{37}$ P. Spade, "Roger Swyneshed's Theory of 'Insolubilia'," 106.

38 Spade and others 'translate' the phrase sicut verba communiter pretendunt as 'as the words commonly pretend': see, e.g., Heytesbury, On "Insoluble" Sentences (trans. Spade, 48-49, discussed at 81-93); and Pironet, "William Heytesbury and the Treatment of Insolubilia," 256. If this means anything at all, it strikes me as at best misleading.
} 
kicked the ball over the fence', then $B$ would have had a different signification, namely, that John didn't kick the ball over the fence. There is no usual signification, only varying signification depending on context. And in the context where Socrates utters $A$, his utterance signifies both that what he said was false and that what he said was true. Neither of these is principal, but merely part of what he said.

Accordingly, the threat to Bradwardine's solution posed by paradox $D$ has been countered. There is no principal signification, different from its total or partial signification, so $D$ says no more than $C$. But the paradox threatened by $C$ is solved by Bradwardine's account. Things are not as $C$ (or $D$ ) signifies, and any inference that they are is fallacious. The theories of his successors, who admitted a distinction between principal and secondary signification, cannot deal plausibly with paradox $D$. But Bradwardine's can, by rejecting the distinction.

Bradwardine's diagnosis of the fallacy in the opponent's appeal to the distinction between principal and consequential signification might, nonetheless, be thought to contain the seeds of its own destruction. For let $E$ be an utterance of 'Things are not as $E$ first represents to the mind', and suppose things are as $E$ first represents to the mind. Then they are not, since that is what $E$ first represents. So by reductio, things are not as $E$ first represents to the mind. But that is what $E$ first represents. So things are indeed as $E$ first represents, as well as not being that way. Contradiction and paradox have returned.

I think this is to misunderstand Bradwardine's response. To be sure, as soon as one part of an utterance's signification can be picked out definitively from the rest, a strengthened paradox can be formed, as in $D$ and $E$. But Bradwardine is telling us that all the parts are equally and integrally parts of the whole - there is no principal signification or primary representation. No part of an utterance's signification is the basis of the rest, as he pointed out. That an insoluble signifies its own truth is not consequential on its signifying its own falsity; and there is no usual or standard signification either which can play that role. So the strengthened paradoxes $D$ or $E$ cannot even be formed, distinct from $C$, and paradox $C$ is resolved by Bradwardine's analysis. 